\title{
Comparative anatomy of male genital organs in the genus Apis
}

\author{
G Koeniger ${ }^{1 *}, \mathrm{~N}$ Koeniger ${ }^{1}, \mathrm{M}$ Mardan ${ }^{2}$, G Otis 2 , S Wongsiri 3
}

\author{
1 Institut für Bienenkunde (Polytechnische Gesellschaft), Universität Frankfurt, \\ Fachbereich Biologie Karl-von-Frisch-Weg 2, D-6370 Oberursel, Germany; \\ 2 University Pertanian Malaysia, Department of Plant Protection, \\ 43400 Serdang, Selangor, Malaysia; \\ ${ }^{3}$ Chulalongkorn University, Faculty of Science, Department of Biology, \\ Bee Biology Research Unit, Bangkok 10500, Thailand
}

(Received 17 January 1991; accepted 30 July 1991)

\begin{abstract}
Summary - Comparative morphological studies of male genitalia from 6 honey bee species revealed distinct qualitative differences in each species in both everted endophalli and endophalli in situ. The endophalli in situ can be studied in drones preserved in ethanol. The following characters are most suitable for classification in situ: 1) pattern of the ventral hairy field of the vestibulum; 2) number of folds and hairy patches of the ventral cervix; 3 ) form of the dorsal hairy field of the cervix; and 4) the form of its appendage (lobe). Three types of endophalli can be classified. One type is present in the cavity-nesting honeybees $A$ mellifera, $A$ cerana and $A$ koschevnikovi, the second in the free-nesting dwart honeybees $A$ andreniformis and $A$ florea and the third in the $A$ dorsata complex.
\end{abstract}

Apis / morphology / reproduction / endophallus / systematics

\section{INTRODUCTION}

In Apis species, especially in $A$ mellifera, there is a broad geographic variation in both morphometric and behavioral characters which when quantified allows the characterization of many subspecies. Maa (1953) classified many of these geographic variants as true species. However, the "well documented quantitative intraspecific variability of $A$ mellifera has to be re- garded as exemplary for selecting species-specific characters within the genus" (Ruttner, 1988). Male genitalia, for example, show qualitative differences in morphology, which are absolutely specific in Apis mellifera, Apis cerana, Apis dorsata and Apis florea (Simpson, 1960, 1970; Ruttner, 1988). This also proved to be true for the recently rediscovered species Apis koschevnikovi (Tingek et al, 1988) and Apis andreniformis (Wongsiri et al, 1990).

\footnotetext{
* Correspondence and reprints
} 
Thus the anatomy of the male genitalia becomes an important tool for the classification into true species or subspecies. In Apis the male copulatory organ is a membranous endophallus. The drone everts it during mating by contracting the abdominal muscles and pumping hemolymph into it. During its insertion into the queen it is encountered by pressure from the small sting chamber and bursa copulatrix. Eversion can be induced artificially by pressing the abdomen, but it is different from the natural eversion in the presence of the queen. The counter-pressure of the queen is missing (Woyke and Ruttner, 1958; Koeniger, 1985, 1986). Further, only with sexually mature and well-fed drones can eversion be induced easily.

The anatomy of endophalli has been studied mostly from everted endophalli. The results are sometimes contradictory, because artificial eversion is often incomplete. As a result the shapes of endophalli of the same species look quite different. For example, there are 3 different drawings of the endophallus of $A$ dorsata: by Simpson (1970), McEvoy and Underwood (1988) and Koeniger et al (1990a). (The drawing by McEvoy and Underwood (1988) is actually of the A laboriosa penis. They found "no diagnostic differences between the male genitalia of $A$ laboriosa and $A$ dorsata"). The drawings of the endophalli of $A$ koschevnikovi and $A$ andreniformis by Mathew and Mathew (1990) again show differences from the previous ones (Tingek et al, 1988; Wongsiri et al, 1990).

Further, it is not possible to obtain everted endophalli from fixed or dried drones. Thus many drone samples cannot be used for studies if only everted endophalli are examined.

To avoid these difficulties and to find an additional method to recognize the characteristic structures of the endophalli, a de- tailed description of the uneverted endophallus in situ could be helpful.

Snodgrass (1956) gives the anatomy of uneverted and everted endophalli in $A$ mellifera. Bährmann (1961) examined the uneverted endophalli of $A$ mellifera, $A$ cerana, $A$ florea and $A$ dorsata from dried museum specimens. He found several diagnostic differences in the morphology of the organ in the 4 species.

In this paper uneverted and everted endophalli of 6 different species are described and compared.

\section{MATERIALS AND METHODS}

Samples of drones were collected in Malaysia: $A$ koschevnikovi $(n=5)$ in Sabah, $A$ andreniformis $(n=5)$ in Johore, $A$ cerana and $A$ dorsata $(n=50)$ in Selangor. Drones of $A$ florea $(n=7)$ were collected in Bangkok, Thailand and drones of $A$ mellifera in Oberursel, Germany.

To study everted endophalli drones were collected during the time of drone flight for each species. By pressing the abdomen between finger and thumb the endophallus was everted (Moritz, 1989). A photo was taken immediately following which the drone was preserved in $70 \%$ ethanol. Fine structures were studied under the microscope (magnification 60-250X).

Uneverted endophalli were dissected and isolated either from freshly killed drones or from drones preserved in $70 \%$ ethanol. After removal of the tergites and digestive tract, the mucus glands were easy to recognize. Then the genital apparatus was isolated by seizing the ductus ejaculatorius between both mucus glands and pulling all the genital apparatus up. The last sternite (sternum 9), penis valves and lamina parameralis were separated from the drone and remained attached to the endophallus. The isolated apparatus was transferred into a new dissections dish and fixed with a needle through the last sternite. Very carefully the cornua were straightened with a small soft brush. The epithelia were removed with the brush until the chitinized structures were easy to recognize. Some samples were stained with methylene blue. The 
isolated genital apparatus was preserved in $70 \%$ ethanol.

\section{RESULTS}

In all Apis species 3 main parts of the membranous endophallus can be distinguished: 1), the vestibulum with cornua and hairy patches; 2 ), the cervix with hairy patches and a special lobe ("fimbriate lobe"); 3) the bulbus.

\section{Uneverted endophalli}

Differences in morphology between the species occurred in all parts (figs 2 and 3 ).

\section{Vestibulum (V)}

\section{The cornua}

All cornua in situ are extremely wrinkled and folded. They can be unfolded and stretched easily when pulled from the tip. The cornua are different in form, length and subdivisions. All species have 1 pair of ventral cornua (vC). Usually one ventral cornus is a simple tube, but in $A$ dorsata each ventral cornus branches into 2 long tubes. The dorsal cornua (dC) are also paired. They are much shorter and have several bulges and notches. In A mellifera, $A$ florea and $A$ andreniformis the bulges are small and at different positions. In $A$ koschevnikovi 3 bulges are elongated into tubes; this elongation is even more pro- a)

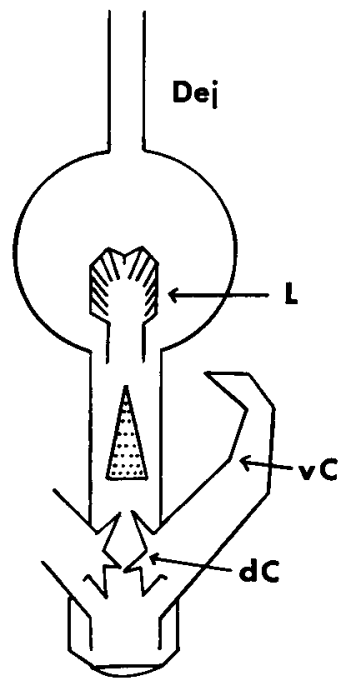

b)

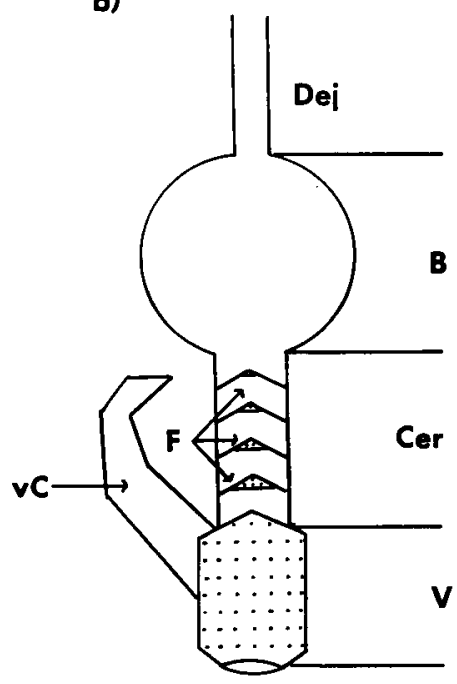

Fig 1. Scheme of an uneverted endophallus: a) dorsal view; b) ventral view. Symbols for all figures: B: Bultus; Cer: cervix; chP: chitinous plates of bulbus; dC: dorsal cornua; Dej: ductus ejaculatorius; F: folds of cervix; L: lobe; V: vestibulum; VC: ventral cornua; 


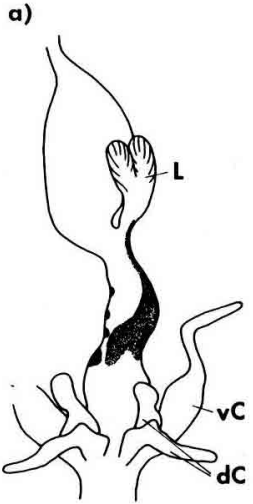

A.c.

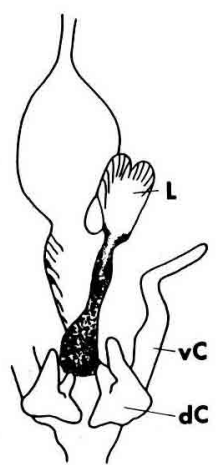

A.k.

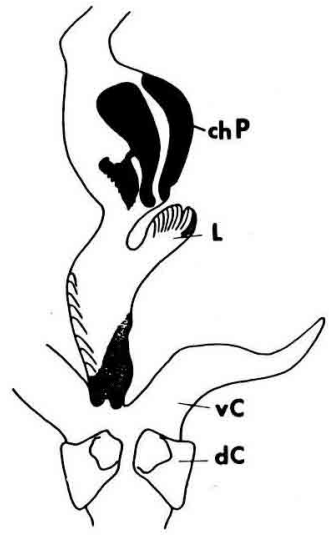

A.m.

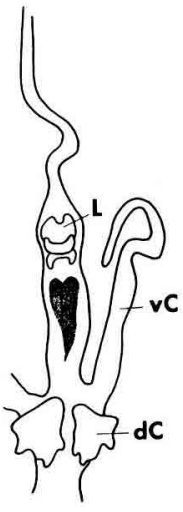

A.f.

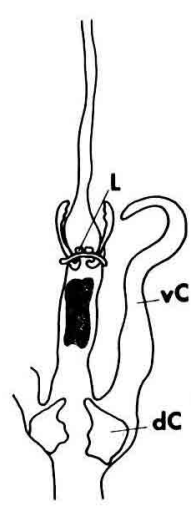

A.a.

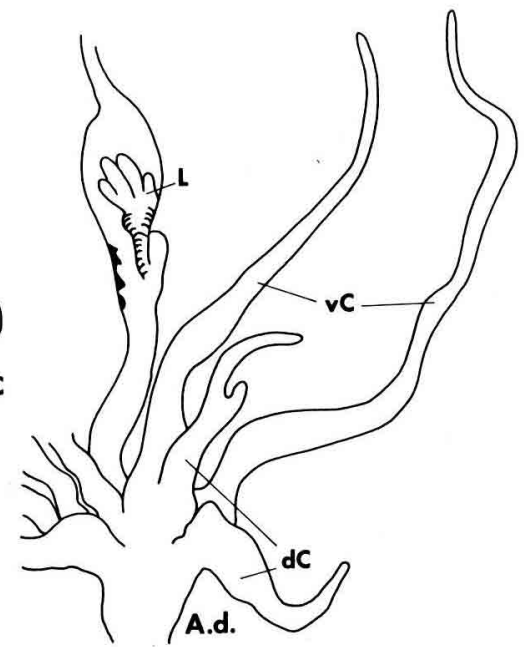

Fig 2. Drawing of uneverted endophalli of 6 Apis species (scale 7:1): a) dorsal view; b) ventral view.

nounced in $A$ cerana. In $A$ dorsata each ventral cornus is elongated into 2 long tubes, 1 of them with an additional bulge.

In all species sexually mature drones (undertaking mating flights) have an orange-colored secretion inside the cornua (Koeniger et al, 1990b).
The hairy fields on the ventral side of the vestibulum in most species are pointed at the border with the cervix. Only in $\mathrm{A} \mathrm{ce}$ rana the border is flat. The density of the hair varies within the field, thus forming different patterns. The field ends in A cerana with a densely haired stripe. 
b)

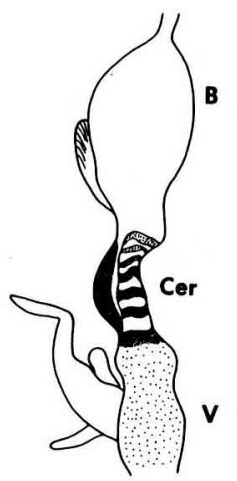

A.c.

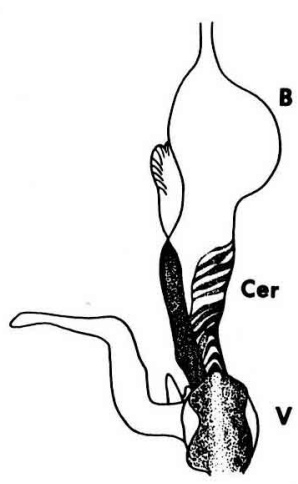

A.k.

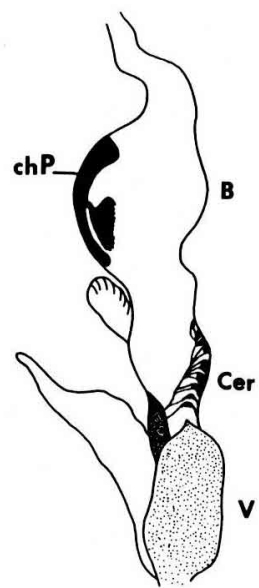

A.m.

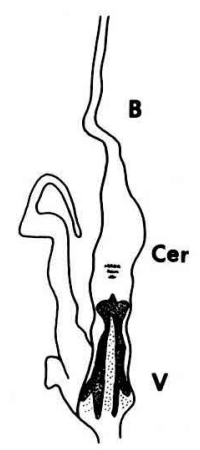

A.f.

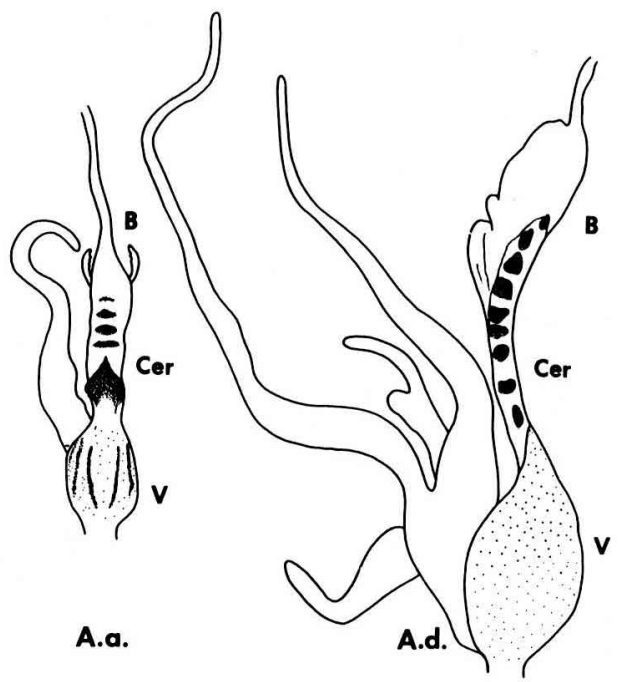

$\mathrm{Aa}=$ A andreniformis $; \mathrm{AC}=A$ cerana $; \mathrm{Ad}=A$ dorsata $; \mathrm{Af}=$ A florea $; \mathrm{Ak}=$ A koschevnikovi $\mathrm{Am}=A$ mellifera .

\section{Cervix (Cer)}

The cervix starts behind the origin of the cornua and the ventral hairy field of the vestibulum and ends after the lobe. Often it is twisted into a spiral. Only in A florea and $A$ andreniformis is it straight.

\section{Hairy patches}

In all species there are hairy patches on the ventral and dorsal side of the cervix.

In $A$ koschevnikovi, $A$ cerana and $A$ mellifera the ventral side of the cervix has folds (FCer) : 6 in A cerana, 10-12 in A 
koschevnikovi and $\approx 9$ in $A$ mellifera. Some of the folds carry hairs. In the other 3 species there are no folds, but different numbers of small hairy patches: 9-11 in $A$ dorsata, 4 in $A$ andreniformis and very thin stripes in $A$ florea. The dorsal hairs form one big patch with different shapes.

\section{The lobe (L)}

The lobe is similar in $\boldsymbol{A}$ koschevnikovi, $\boldsymbol{A}$ mellifera and $A$ cerana. It has a notch at the end, and each side has 13-15 fringes (fimbria). In $A$ cerana the notch is much deeper than in the other 2 species. The lobe of the free-nesting types has no fringes (fimbria). In $A$ dorsata it has 4 deep notches that divide the lobe into 4 unscored appendages. The lobes of $A$ florea is subdivided into 3 different bulges, and $A$ andreniformis has one lobe with one pair of long thin appendages and 3 pairs of short ones.

\section{Bulbus (B)}

The bulbus of $A$ mellifera is large and has chitinous plates (chP), which are not present in the other species. The bulbus in $A$ dorsata is relatively small compared to that of $A$ cerana, $A$ koschevnikovi and $A$ mellifera. The bulbus opens into the ductus ejaculatorius (Dej). This junction forms the gonoporus in the everted endophallus. In $A$ andreniformis and $A$ florea the bulbus is a thin tube and its apex cannot be distinguished from the beginning of the ductus ejaculatorius.

\section{Everted endophalli}

During eversion the endophallus is filled by hemolymph and air to increase its stability by inner pressure. The former "inside" then becomes the "outside". All wrinkles and folds are extended and as long as the high pressure persists all endophalli have typical curves and shapes (fig 4).

\section{Vestibulum (V)}

The ventral cornua (vC) of $A$ mellifera, $A$ koschevnikovi and $A$ cerana first extend posteriorly but the tips are recurved ventrally to different degrees. This is opposite in $A$ andreniformis and $A$ florea, where the cornua curve back dorsally. The 2 long tubes of the ventral cornua of $A$ dorsata are coiled to a spiral.

The dorsal cornua (dC) are smaller and have 2 or 3 appendages. In $A$ koschevnikovi they look like little balls; in $A$ cerana they form small tubes. $A$ dorsata drones have the longest dorsal cornua ( 3 tubes); A mellifera drones have the shortest dorsal cornua (one bump). The orange secretion of the everted cornua covers their outer surface.

The hairy patches on the ventral side correspond to the shapes in situ, but because of the extension of the vestibulum the hairs appear less dense.

\section{Cervix (Cer)}

The cervix, which is a thin tube at the beginning of the eversion, is soon widened to a thick duct in $A$ mellifera and $A$ cerana. The spiral character has vanished. The duct is a little elongated in $A$ koschevnikovi and long and thin in $A$ dorsata. The ventral hairy patches are placed on little humps, but it is difficult to recognize the same number of humps as folds in the uneverted endophallus. Presumably the extension of the cervix eliminates some of them.

The relative length of the extended cervix - measured from the end of the ventral hairy field of the bulbus to the orifice of the lobe - is different. It is one quarter of the total length of the endophallus in A mellife- 
ra, one third in $A$ cerana, two fifths in $A$ koschevnikovi, and one half in $A$ dorsata. In $A$ andreniformis and $A$ florea it is less than one quarter. In the uneverted stage the cervix has about the same length in 5 species. A dorsata is the only exception, because the cervix is not folded.

The dorsal hairy patches are broadened but show similar shapes as in the uneverted endophallus.

The lobes have the same characteristic number of fringes (fimbria) and subdivisions as they have in situ. However, they are extremely extended by pressure, thus changing the shape considerably.

\section{Bulbus}

The bulbi are bent dorsally in A mellifera, $A$ cerana and $A$ koschevnikovi. They often contain mucus and sometimes the mucus is ejaculated but remains on the outer surface of the bulbus. The bulbus of $A$ mellifera contains chitinous plates (chP).

The bulbus of $A$ dorsata is bent ventrally and is smaller than in the former species. It also contains some mucus. In $A$ andreniformis and $A$ florea the bulbus forms a thin tube and is rather pointed apically. Mucus was not recognized.

\section{DISCUSSION}

In all species examined, distinct qualitative differences in the morphology of the endophallus could be recognized. Comparing endophalli in situ gives a reliable method to classify the Apis species, using fresh or preserved drones. Even dry specimens can be used for examination (Bährmann, 1961). This method may help to clarify whether there are differences between the endophalli of $A$ dorsata and $A$ laboriosa, a question still under debate (Koeniger et al, 1990a).

The following characters are clearly different in the uneverted endophalli of the 6 examined species : 1) pattern of the ventral hairy field of the vestibulum; 2) number of folds and hairy patches of the ventral cervix; 3), form of the dorsal hairy field of the cervix; and 4), the form of its lobe.

On the other hand, during preparation of endophalli in situ the length and form, particularly of the cornua and cervix, may be changed. These parts are easily stretched because they are extremely wrinkled and folded.

Everted endophalli give additional information which cannot be obtained with endophalli in situ. For example, the bend of the cornua either dorsally or ventrally cannot be recognized in the uneverted organ. The same is true for the bending of the bulbus, which also differs between the species. While the bulb turns dorsally in the cavity-nesting species, it turns ventrally in $A$ dorsata. Also in $A$ andreniformis and $A$ florea the thin bulb turns ventrally directly after the lobe, then forming a "dorsal hook".

The different length of the cervix can also only be easily recognized in the everted stage. Its length steadily increases from A mellifera, $A$ cerana to $A$ koschevnikovi. The longest and thinnest cervix is in $A$ dorsata. The dwarf honeybees $A$ andrenifor$m i s$ and $A$ florea have extremely short cervices.

Evaluating the endophalli, both in situ and in the everted state, one can distinguish 3 main types : 1), the bulbus is thick and bent dorsally; the ventral cornua is bent ventrally; production of mucus and lobe with fimbria are observed. This type is found in the cavity-nesting species: $A$ mel- 

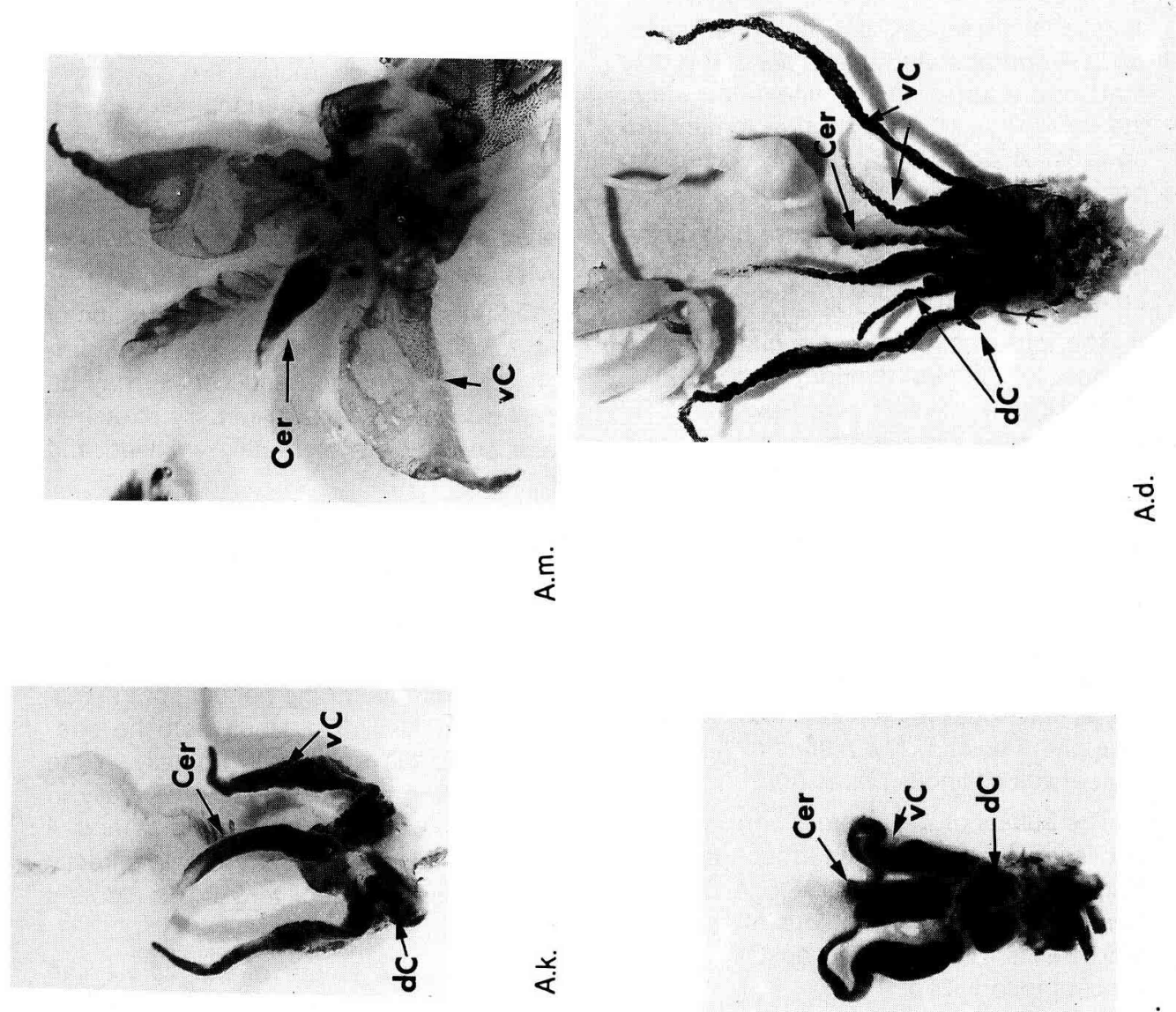

$\stackrel{ஷ ்}{<}$
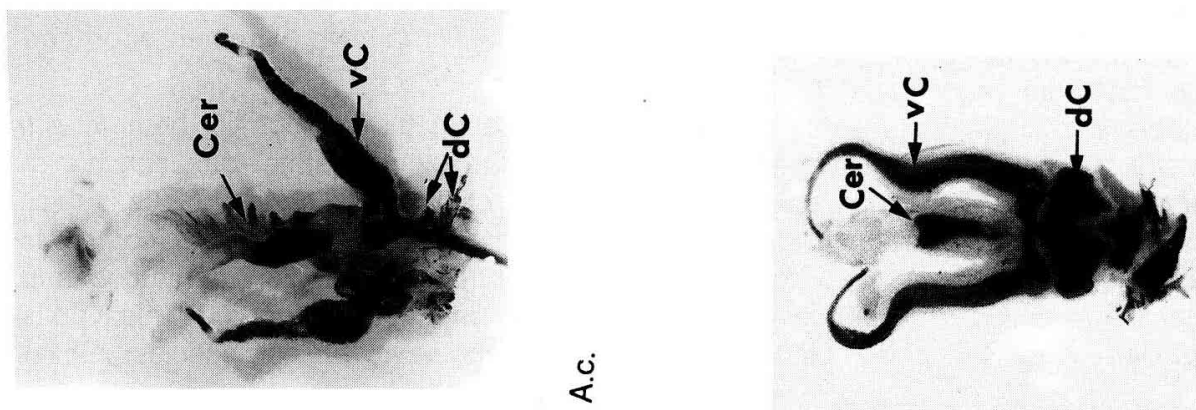

(i 

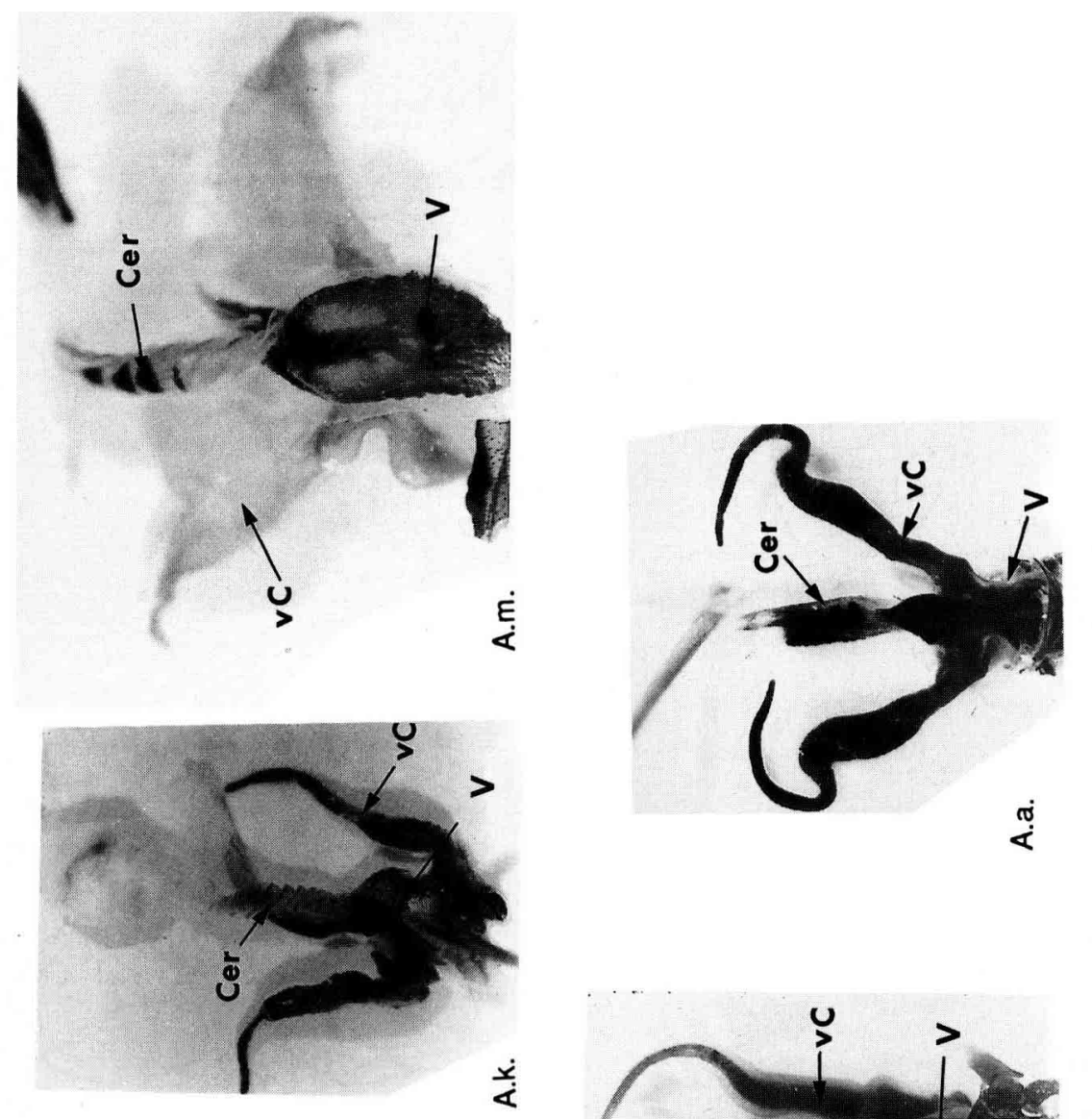

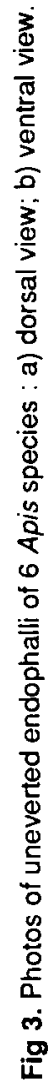
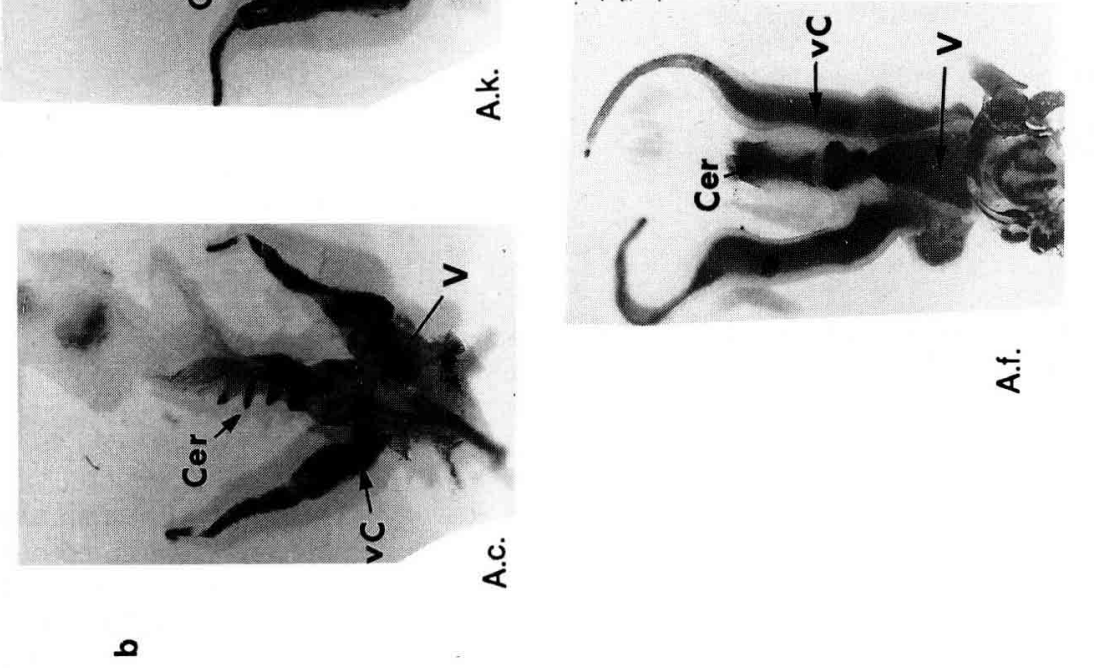


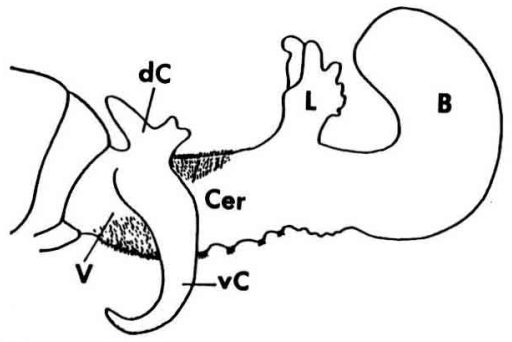

A.f.

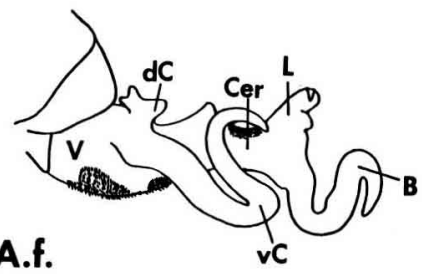

A.c.
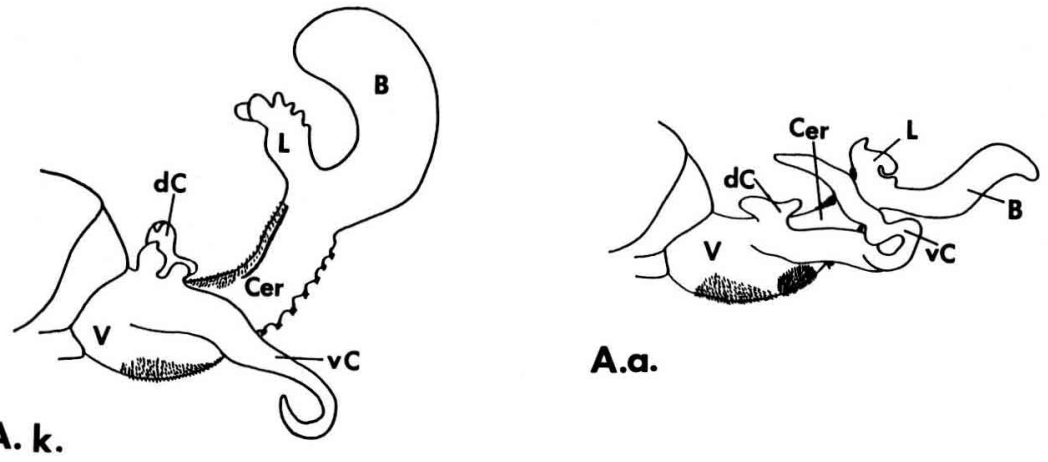

A.a.

\section{A. $\mathbf{k}$.}
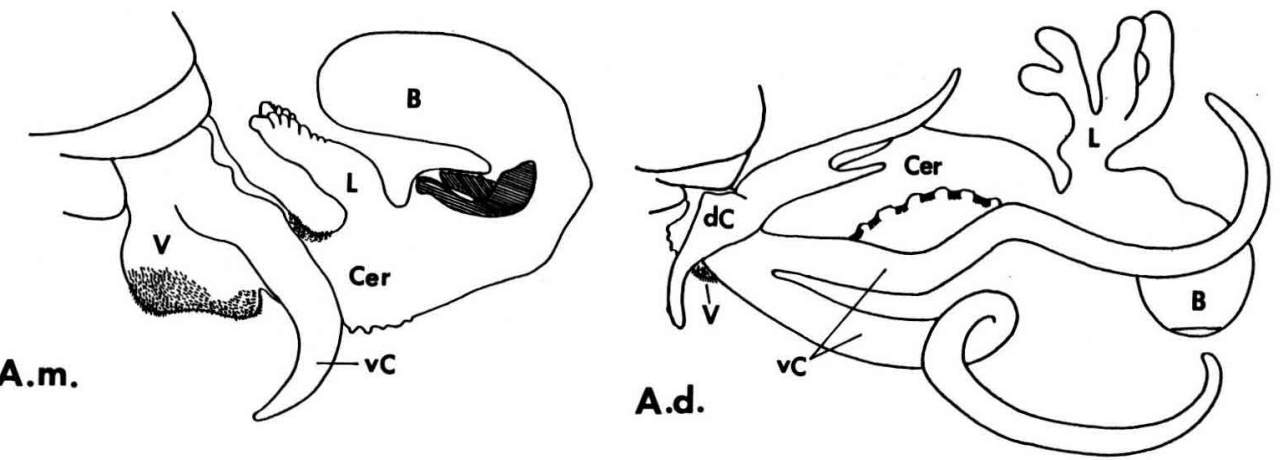

Fig 4. Drawings of everted endophalli of 6 Apis species (lateral view).

For abbreviations, see figs 1 and 2.

lifera, A cerana and A koschevnikovi; 2), The bulbus is thin and elongated; the cervix short, the ventral cornua bent dorsally; there is little or no mucus; the lobe is without fimbria. This type is found in freenesting dwarf honeybees $A$ andreniformis and $A$ florea. 3) The bulbus is small and bent ventrally; there are ventral cornua with 2 long tubes; the lobe is divided into 4 parts and is without fimbria; the cervix is extremely long. This type is found in the dorsata group. 
The differences in morphology may provide additional information for evaluating the relation and the phylogeny of the honey bee species. Form, course and length of the bulb and the cervices seem to be suitable for this evaluation, especially in combination with sperm number and the mechanism of sperm transfer (Koeniger and Koeniger, 1990a,b; Koeniger et al, 1990c).

Little is known about intraspecific variation of morphological characters. For example, the number of hairy patches of the cervix varies between 9-11 in $A$ dorsata drones from 1 colony. Further, the type of hairs on the endophallus might be useful for both inter- and intraspecific variations. In A mellifera, Woyke (1958) describes 7 different types of hairs on different parts of the endophallus. Thorough studies of intraspecific variation of the endophalli are still lacking.

\section{Résumé - Étude comparée de l'organe} génital mâle dans le genre Apis. L'étude morphologique comparée des endophallus, après leur éversion, a révélé des différences nettes entre les 6 espèces d'abeilles (Ruttner, 1988; Tingek et al, 1988; Wongsiri et al, 1990). Souvent, l'éversion artificielle est incomplète. Par conséquent, des dessins d'endophallus de la même espèce ne sont pas toujours identiques (Koeniger et al, 1990). Pour remédier à ces difficultés, des études comparatives d'endophallus in situ ont été réalisées chez A koschevnikovi, A cerana, A mellifera, $A$ dorsata, $A$ florea and $A$ andreniformis. Ces résultats ont été comparés à ceux des endophallus après éversion. Les mâles ont été collectés en Malaisie, en Thaillande et en Allemagne, et conservés dans l'éthanol à $70 \%$.
Le plan d'organisation de l'endophallus membraneux est identique chez toutes les espèces d'Apis. Trois parties principales peuvent être distinguées (fig 1):

1) Le vestibule (V) avec des cornules ventrale et dorsale ( $v C$ et $d C$ ), et une aire pileuse.

2) Le cervix (Cer), qui comporte également des surfaces pileuses et un lobe spécial (le lobe feuilleté).

3) Le bulbe (B).

Dans ces différentes parties, il y a des différences nettes entre les espèces d'abeilles (figs 2, 3 et 4 ) :

1) Les aires pileuses du vestibule ont une forme différente dans chaque espèce.

2) Les cornules (C) sont subdivisées en une partie ventrale (VC) et une partie dorsale (dC). La forme et la taille sont différentes, mais une sécrétion de couleur orange est présente dans toutes les espèces.

3) La longueur du cervix (Cer) est différente : $A$ dorsata a un très long cervix; il est très court chez $A$ florea et $A$ andreniformis, ce qui rend sa reconnaissance aisée dans l'endophallus après éversion. Les différences suivantes sont plus faciles à mettre en évidence dans des endophallus in situ : nombre des petites taches poilues et des plis du côté ventral, forme des surfaces pileuses dorsales.

4) Le lobe feuilleté (L) a des poils seulement chez les espèces nichant à l'intérieur de cavités; chez A dorsata, le lobe est divisé en 4 prolongements. Le lobe d'A florea est subdivisé en 3 renflements différents, et $\boldsymbol{A}$ andreniformis a un lobe comportant une paire d'appendices longs et minces et 3 paires d'appendices courts. Les différences dans ce lobe sont plus faciles à reconnaître dans l'endophallus in situ. 
5) Le bulbe est hypertrophié uniquement chez les espèces nichant dans des cavités, et chez $A$ dorsata, il est rempli de mucus au cours de l'éversion. II comporte des plaques chitineuses spéciales (chP) uniquement chez $A$ mellifera. Chez $A$ florea et $A$ andreniformis, le bulbe forme un tube long et fin et se termine en pointe.

Les endophallus in situ montrent suffisamment de différences qualitatives entre les espèces pour être utilisés pour la classification de ces espèces. Les endophallus in situ et après éversion, permettent de séparer 3 types différents :

1) Les espèces d'Apis nidifiant dans des cavités ont un bulbe bien développé, qui se recourbe dorsalement après éversion, et qui contient du mucus; les cornules sont courbées ventralement après l'éversion; le lobe du cervix est feuilleté.

2) Les abeilles naines $A$ florea et $A$ andreniformis ont un bulbe long et fin, qui contient peu ou pas de mucus; les cornules sont courbées dorsalement après l'éversion; le cervix est très court et le lobe n'est pas feuilleté.

3) Le groupe dorsata a un bulbe relativement plus petit, qui se recourbe dorsalement après l'éversion. II contient du mucus; le cervix est très long, son lobe a 4 appendices. Les cornules ventrales sont branchées dans 2 longs tubes enroulés. Les cornules dorsales se ramifient en 3 parties.

\section{Apis / endophallus / morphologie / re- production / systématique}

\footnotetext{
Zusammenfassung - Vergleichende Anatomie der männlichen Begattungsorgane innerhalb der Gattung Apis. Vergleichende morphologische Studien von evertierten Endophalli der Drohnen haben gezeigt, daß bei 6 Honigbienenarten deut-
}

liche Unterschiede bestehen (Ruttner, 1988; Tingek et al, 1988; Wongsiri et al, 1990). Da die künstliche Eversion häufig in einem unterschiedlichen Stadium stehen bleibt, sind Zeichnungen vom Endophallus derselben Rasse manchmal unterschiedlich (Koeniger et al, 1990). Um diese Schwierigkeiten zu vermeiden, wurde eine vergleichende Untersuchung von Endophalli in situ bei $A$ koschevnikovi, $A$ cerana, $A$ mellifera, $A$ dorsata, $A$ florea and $A$ andreniformis gemacht. Diese $\mathrm{Er}$ gebnisse wurden mit den Befunden der evertierten Endophalli verglichen.

Die Drohnen wurden in Malaysia, Thailand und Deutschland gesammelt und in $70 \%$ Ethanol aufbewahrt.

Der Endophallus ist häutig und in dieser Form nur bei Apis Arten vorhanden. Er weist bei allen Arten eine verwandtschafliche Beziehung auf. Er ist immer in drei Zonen untergliedert (Abb 1, 2 und 3) : 1) Das Vestibulum (V) mit ventralen und dorsalen Cornua (vC und dC) und Haarfeldern; 2) die Cervix (Cer) ebenfalls mit Haarfeldern und einem lappigen Anhang (L); 3) der Bulbus (B), das Endstück.

Die einzelnen Abschnitte weisen innerhalb der Apis Arten deutliche Unterschiede im Bau auf :

1) Die Haarfelder am Vestibulum haben bei allen Arten eine unterschiedliche Form.

2) Die Cornua (C) unterteilen sich in einen ventralen $(\mathrm{vC})$ und dorsalen $(\mathrm{dC})$ Teil. Sie sind bei allen Arten verschieden geformt und auch unterschiedlich lang. Alle haben ein orangefarbenes Sekret.

3) Die Länge der Cervix ist verschieden, $A$ dorsata hat eine besonders lange Cervix, $A$ florea und $A$ andreniformis dagegen eine besonders kurze, was leicht im evertierten Zustand zu erkennen ist. Die Anzahl von kleinen Haarfelder und Falten an der Ventralseite ist unterschiedlich, ebenso die Form des Haarfelds auf der 
Dorsalseite. Das wiederum ist leichter in situ zu sehen.

4) Der "Federanhang" ( $L$ ) ist nur bei den höhlenbrütenden Arten, $A$ mellifera, $A$ cerana und $A$ koschevnikovi federförmig. Beim Endophallus in situ ist in der Mitte eine Kerbe zu erkennen, die bei $A$ cerana tief eingeschnitten ist. Der Anhang bei $A$ dorsata ist grob vierlappig, bei $A$ andreniformis ist der Anhang $\mathrm{zu}$ verschieden langen dünnen Schläuchen ausgezogen, bei $A$ florea sind nur kurze Ausläufer vorhanden. Die Unterscheidung des "Federanhangs" ist am deutlichsten am nicht evertierten Endophallus zu erkennen.

5) Der Bulbus ist bei den höhlenbrütenden Arten und $A$ dorsata zwiebelförmig erweitert und ist im evertierten Zustand mit weißem Mucus gefüllt, bei $A$ mellifera enthält er zusätzlich paarige Chitinspangen. Bei $A$ andreniformis und $A$ florea ist der Bulbus lang ausgezogen und endet in einer Spitze.

Endophalli in situ lassen ausreichend qualitative Unterscheide zwischen den Arten erkennen, um sie zur Klassifizierung zu benutzen. Sowohl Endophalli in situ als auch im evertierten Zustand zeigen, daß es 3 Typen gibt.

Die höhlenbrütenden Honigbienenarten haben einen dicken, dorsal gebogenen Bulus, der im evertierten Zustand Mucus enthält, die Cornua sind ventral gebogen, der Anhang an der Cervix ist federförmig.

Bei den Zwerghonigbienen $A$ andreniformis und $A$ florea ist der Bulbus dünn und lang und enthält wenig oder keinen Mucus, die Cornua sind dorsal gebogen, die Cervix ist sehr kurz und ihr Anhang ist nicht federförmig.

Bei $A$ dorsata ist der Bulbus relativ klein und dorsal gebogen und enthält Mucus. Die Cervix ist extrem lang, ihr Anhang besteht aus 4 ungekerbten Lappen, die ventralen Cornua sind zweigeteilt und sehr lang ausgezogen. Auch die dorsalen Cornua sind relativ lang und sind dreigeteilt.

\section{Apls / Morphologie / Reproduktion / Endophallus / Systematik}

\section{REFERENCES}

Bährmann R (1961) Über den Bau des Begattungsschlauches von vier Apis-Arten. Leipziger Bienenztg 75, 18-20

Koeniger G (1985) Funktionsmorphologische Befunde bei der Kopulation der Honigbiene. Apidologie 15, 189-104

Koeniger $\mathrm{G}$ (1986) Mating sign and multiple mating. Bee World 67, 141-159

Koeniger G, Koeniger N (1990a) Unterschiedliche Genese der Polyandrie bei Apis-Arten. In: Verh Dtsch Zool Ges (Pfannenstiel HD, ed) Gustav Fischer Verlag, Stuttgart, 618

Koeniger G, Koeniger N (1990b) Evolution of reproductive behavior in honey bees. In: Social Insects and the Environment (Veeresh GK, Mallik B, Viraktamath $C A$, eds) Oxford and IBH Publ Co, Lid, Bombay India, Proc 11th Int Congr IUSSI, India, 101-102

Koeniger G, Mardan M, Ruttner F (1990a) Male reproductive organs of Apis dorsata. Apidologie 21, 161-164

Koeniger G, Wissel M, Herth W (1990b) Cornual secretion on the endophallus of the honeybee drone (A mellifera). Apidologie 21, 186191

Koeniger G, Koeniger N, Mardan M, Punchihewa RWK, Otis G (1990c) Numbers of spermatozoa in queens and drones indicate multiple mating of queens in Apis andreniformis and Apis dorsata. Apidologie 21, 281-286

Maa TC (1953) An inquiry into the systematics of the tribus Apidini or honeybees (Hymenoptera). Treubia 21, 525-640

McEvoy M, Underwood BA (1988) The drone and species status of the Himalayan honey bee, Apis laboriosa (Hymenoptera: Apidae). $J$ Kansas Entomol Soc 61, 246-249

Mathew KP, Mathew S (1990) Further observations on characters and behaviour of Apis koschevnikovi, the "red honeybee" of Sabah. Bee World 71, 61-66 
Moritz RFA (1989) The insemination procedure. In: The Instrumental Insemination of the Queen Bee (Moritz RFA, ed) Apimondia, Bucharest, pp 67

Ruttner F (1988) Biogeography and Taxonomy of Honeybees. Springer Verlag, Berlin

Simpson H (1960) Male genitalia of Apis species. Nature 185, 56

Simpson H (1970) The male genitalia of Apis dorsata L. (Hymenoptera: Apidae). Proc $R$ Entomol Soc Lond A 45, 169-171

Snodgrass RE (1956) The Anatomy of the Honey Bee. Cornell University Press, Ithaca, NY

Tingek S, Mardan M, Rinderer TE, Koeniger N, Koeniger G (1988) Rediscovery of Apis vechti (Maa, 1953): the Saban honeybee. Apidologie 19, 97-102

Wongsiri $S$, Limbipichai $K$, Tangkanasing $P$, Mardan M, Rinderer TE, Sylvester HA, Koeniger G, Otis G (1990) Evidence of reproductive isolation confirms that Apis andreniformis (Smith, 1858) is a separate species from sympatric Apis florea (Fabricius, 1787). Apidologie 21, 47-52

Woyke J (1958) The histological structure of the reproductive organs of the drone. Poznan Soc Friends Sci 19, 1-51 (in Polish, English summary)

Woyke J, Ruttner F (1958) An anatomical study

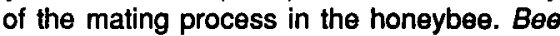
World 39, 3-18 